\title{
Environmental Psychology Approach: Understanding Tourist's Intention to Reducing Food Waste in Badung Regency, Bali, Indonesia
}

\author{
Indah Andesta \\ Master of Tourism, Society and Environment \\ Wageningen University Research, The Netherlands \\ Email: andesta56@gmail.com
}

\begin{abstract}
Bali is one of the destinations with the highest tourist visiting in Indonesia. One concern is food waste produced by tourists during the holiday. Most of the food waste comes from consumers level. Thus, needed to understand what factors influence of tourist's intention to reduce food waste during the holiday. This study aims to understand tourist behavioural intention of reducing food waste during the holiday. The conceptual model was built based on the new environmental paradigm scale and environmental psychology approach. There are six hypotheses designed through environmental attitude, feeling personal responsibility, knowledge and intention to reduce food waste during vocation. Correlation and multiple regression were chosen to analyse the data. Environmental attitude did not have a direct association of tourist's intention to reduce food waste ( $p$-value=.23). Meanwhile, feeling personal responsibility and knowledge to reduce food waste has a significant relationship with the outcome ( $\mathrm{p}$-value $=.001)$. In the environmental attitude, both local and foreign tourists are not profoundly correlated with the understanding of tourist's intention to reduce food waste during the holiday. Overall, the study concludes that tourists can figure out the intention of reducing food waste, even though they do not concern about general environmental attitude.
\end{abstract}

Keywords: Environmental Psychology Approach, Tourist's Intention, Reducing Food Waste, Bali

\section{Background}

Indonesia is the second-largest contributor to food waste in the world (Fixing food, 2016), every year, Indonesia disposes of around $300 \mathrm{~kg}$ perc pita of food waste. Increasing organic waste in Badung regency cannot be separated from the increasing number of tourists visiting Badung Regency, Bali, the impact is the garbage would be disturbing tourist's activities in Badung Regency. Thus, waste is a fundamental problem in Bali. It is necessary to integrate the commitment of behavioural changes by consumers. The rapidly growing tourism sector in Badung Regency is followed as well by an increase in the volume of waste. Badung Regency produces
286 tons or 8,858 tons per month, 104,390 per year (Beritabali.com, 2018). Merthawan as Head of The Environment and Hygiene Agency said that $40 \%$ of total waste in Badung comes mostly from tourism services and the rest from households (Beritabali. com, 2018).

Furthermore, based on Beritabali.com (2018) in Bali the biggest of waste is produced from organic waste $(90 \%)$, followed of inorganic waste $(9,5 \%)$ and $\mathrm{B} 3$ waste $(0,5 \%)$.

EcoBali Recycling (2018) added that around $65 \%$ of the waste produced is food waste, where food waste will produce methane, a gas 25 times stronger than $\mathrm{CO} 2$ which contributes to the 
phenomenon of climate change. The infrastructure and transportation play in reducing food waste; consumers also become one of the factors that cause increased food waste. Furthermore, the increase of waste in Badung Regency is caused by several things such as lifestyle changes and lifestyle adaptations from traditional to western.

\section{Reducing food waste in general and in the tourism context}

Reducing food waste is one part of the commitment of sustainable development goals (SDGs) 12, which is ensuring sustainable consumption and production. If a person always leaves food, this contributes to natural sources running out faster. Young et al. (2018), Graham-Rowe et al. (2014) and Russell et al. (2017) estimate that in a year, one-third of food is wasted by the consumers. Decreasing food waste is a global challenge, and it connects the effects of attitude, habit, emotions and perceived values (Russel et al., 2017).

Furthermore, food waste is caused by all stakeholders, farmers, industry, retailers, and consumers. Consumers are the biggest sources of food waste. In order to reduce food waste, it is important to understand consumer motivation and their management skills and what is influencing them to reduce food waste (Visschers and Siegrist, 2016).

A South African survey found that date labelling was not working for consumers; they had a different perception about date labels (Taufigue et al., 2016). For example, this meant that some people were confused about the start and expiry dates of food products. When it comes to food waste, consumers often know how to handle their food in a household stage. However, unfortunately, people do not react following their knowledge.

Tourists who come to restaurants, tend to search for excellent service, good quality of food and restaurant decoration (Susskind and Chan, 2000; Erkmen and Hancer, 2018). Food quality was a pivotal factor to explain tourist's behaviours in restaurants (Ha and Jang, 2010; Namkung and Jang, 2007; Sulek and Hensley, 2004). There are some factors which suggest food quality such as smell, serving size, the freshness of food, menu varieties, presentations, the tastiness of the food, and nutritional value (Kivela et al., 2000; Raajpoot,
2000; Ekrmen and Hencer, 2018). When people consume food, they have different motivations like pleasure, enjoyment, interaction with other people, taste, or just for fun (Erkmen and Hancer, 2018).

Bali Buda is one of the restaurants in Bali that provides organic food, and one of Bali Buda programs is reducing food waste from production to consumer. One of Bali Buda methods reducing food waste at the consumers' stage is presented on the menu where they provide ingredients if for others at the same price. The consumers can also request to skip one of the items they do not like. The next thing that is done by Bali Buda is that they make ingredients with varied flavours. Thus the consumer does not feel bored (Keisha, 2019). This is one strategy that is also used to reduce food waste. Keisha (2019) added that the most commonly leftover ingredient from consumers is rice. However, the restaurants state that the portion of rice cannot be reduced in size because it is the standard of the Bali Buda restaurants.

This research aims to understand of tourist's behavioural intention. Within this study, concern mainly on the case of food waste during holiday and on both local and foreign tourists, the relationship between new environmental paradigm scale, includes different kinds of factors influencing significant environmental behaviour of tourist's intention to reducing food waste during the holiday. In the end, it is designed for this research can be used to create the precise recommendation to tourism industries, non-governmental organisation and policymakers in order to determine or tourist's behaviours when travelling related to the environment changing in a tourism destination. The objective of this research was 'to understand which factors predict reducing of food waste behaviour of both local and foreign tourists will be the highest significantly influence to tourist's intention to reduce food waste during the holiday in Badung regency, Bali? To succeed objective, the research questions were: 'which factors predict tourist's behavioural intention toward reducing food waste between local and foreign tourists during the holiday in Badung regency, Bali?'. Variables that possibly essential to predict behavioural intention were tested by utilised value belief norm theory from variables of environmental psychology approach. 


\section{Theoretical Framework}

\section{Environmental Psychology}

Environmental psychology is "about the relationship between humans and the environment", which in turn has a relationship with environmental issues; there is a human action effect on the environment (Bonnes, 2017). In this study, environmental psychology is used as a concept to support tourist's intention of reducing food waste. Environmental psychology provides a means to determine a person's attitude towards the decision. When making a decision, the outcome cannot be measured solely based on past experiences; it depends on the person's intention in a particular case.

In daily activities, people may not be consciously doing activities that give bad or good impact for the environment, that can be realised through responsible behaviour or environmental protection; those concepts have same meaning with pro-environmental behaviour (Miller et al., 2015; Kollmus and Agyeman, 2002; Cottrell, 2003; Le and Oh, 2018; Lee, 2013; Ficko \& Bončina, 2019). In tourism, the context was evidenced through the tourist's responsibility during the holiday (Miller, et., 2015).

According to Miller et al. (2015), there is a divergence in the amount of responsibility towards pro-environmental practices that people take between when travelling and when they are at home. When tourists travel, they should be environmentally friendly to decrease negative environmental impacts that are caused by a large number of tourists visiting a site (Juvan and Dolnicar, 2017).

\section{Theory of Environmental Psychology}

Value belief norm (VBN) is used to construct my conceptual model to produce the output of tourist's intention reducing food waste when travelling in Bali. VBN, as a theory, is usually used for activities related to the current environment (Stren and Guagnano, 1995).

VBN theory has been developed by norm activation theory (Stren, 2000). According to Schwartz (1977), one indicator or component of norm activation theory is situational responsibility, where individuals have a responsibility for a situation that will cause a consequence. Furthermore, personal feelings influence behaviour to perform in a proenvironmental manner, in which pro-environmental behaviours are the impact of the efforts given by individuals (Harland et al., 2007). To understand of tourist's intention reducing food waste, in value belief norm theory is used some components such as new environmental paradigm to see the relationship between humans and the environment. The perceived ability to reduce impacts that are applied by feeling personal responsibility and lastly the intention of pro-environmental behaviours.

Besides, Gifford and Sussman (2012) explained nine factors are influencing significant environmental behaviours such as childhood experience, knowledge, personality, values and worldviews, norms, place attachments, habit, affect, and demographics. In this study, not all of those factors can contribute to analysing tourist's intention of reducing food waste.

Besides, combating of environmental attitude, feeling personal responsibility, and intentions of components from VBN theory with knowledge of pro-environmental concern and behaviour (Gifford and Nilsson, 2014).

\section{Environmental Attitude}

According to Gifford and Sussman (2012), environmental attitudes are an essential part of behaviour control, which either declines or increases ecological quality between humans and nature. Environmental attitude can measure knowledge, affect, and intention based on conventional perception (Maloney et al., 1975). Generally, to measure the environmental attitude, the components of the new environmental paradigm (NEP) scale - founded by Dunlap and Van Liere (1978) and consisting of 15 items (Dunlap et al., 2000) - can be used. The NEP scale is focused on humans that disturb the environmental, social, and economic sectors and make the Earth unbalanced (Pienaar et al., 2013).

\section{Feeling Personal Responsibility}

Researchers have said that the amount of perceived responsibility can be seen as a predictor of ecological behaviour (Arbuthnot, 1977; Fridgen, 1994; Granzin and Olsen, 1991; Heberlein and Black, 1976; Hines, 1984). Responsibility depends on to what extent a person sees the consequences of an environmental 
problem, and responsibility increases with how much the person was ready to have a sense of responsibility to be pro-environmental (Wang et al., 2014). Feeling personal responsibility stems from problem awareness, which affects whether someone has the intention to tackle the problem or not (Lindenberg and Steg, 2007; Steg and Groot, 2009).

\section{Environmental knowledge}

Environmental knowledge is consciousness about environmental issues and how to tackle those issues (Polonsky et al., 2012). There exists a relationship between pro-environmental behaviour and environmental knowledge (Kollmuss and Agyeman, 2002), and by providing education to people regarding important environmental issues, there will be an impact on pro-environmental behaviour. A person's environmental knowledge is formed since childhood based on experiences which are influenced by both the external and internal environment (Chawla, 1999).

\section{Environmental intention}

The intention is the tendency of someone to choose to do or not do something. This intention is determined by the extent to which a person has a positive attitude towards a particular behaviour, and to what extent - if he chooses to do that particular behaviour-he got support from other people who influence his life (Ajzen, 2005). According to Han et al. 2010, the intention was a factor for predicting pro-environmental behaviour, and intention revealed a decision that a person takes to support or implement specific actions regarding pro-environmental behaviour (Ajzen, 1985).

\section{Theoretical framework}

Tourist's intention to reduce food waste is a part of environmental psychology as a variable used to measure environmental behaviour. None of the environmental psychology factors is used to measure the tourist's intention. This study began with a general part about the new ecological paradigm scale to help a better understanding of the relation between human and environment in the specific part of pro-environmental.

Furthermore, to separate between local and foreign tourists were used demographic variables. This will be used to see whether they have a difference of intention to reduce food waste when travelling in Bali.

Figure 1 presents the conceptual model used to measure the tourist's intention in reducing food waste.

That concept is the same with the value belief norm theory, which is to explain from the general part of the value to the specific part of pro-

Figure 1. Conceptual model of tourist's intention reducing food waste

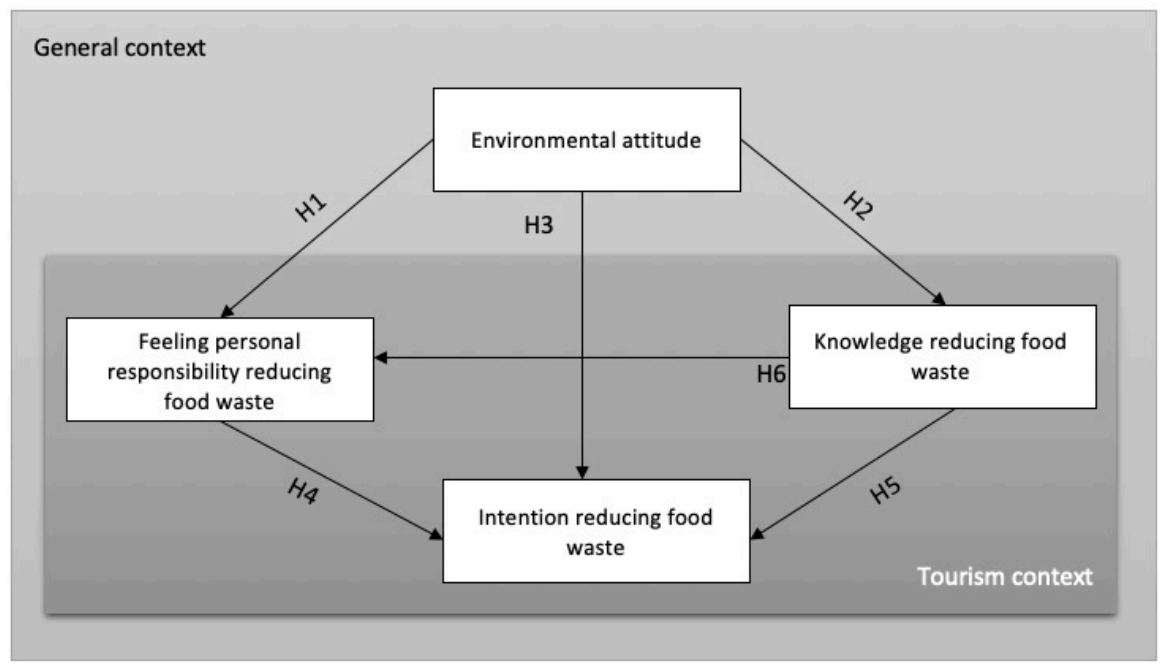

Source: Maarten (2019) from Stern (2000) and Kollmuss and Agyeman (2002) 
environmental (Stern, 2000). In my study, starting the general part with environmental attitude consists of new environmental paradigm statements.

Environmental attitude has a link with feeling personal responsibility, knowledge, and as well as intention. Feeling personal responsibility contains statements about actions to reduce the food waste that has been indicated by favourable or unfavourable. While knowledge tends to the ability of people to reducing food waste when travelling. Furthermore, this study also sees the relation between knowledge with feeling a personal responsibility for reducing food waste. To directly understanding the intention would be noticed with felling personal responsibility and knowledge. Intention means statements related to the people's intention of reducing food waste when travelling, such as people intend not to throw food away.

This will be used to understand whether they have a difference either of intention to reduce food waste or not. Childhood experience is not used in this study because travelling is not a daily activity. According to Fishbein et al., (1980), childhood experience as past behaviour is an important variable to measure intention when the events are a habit of human or daily activities.

In the conceptual model, the environmental attitude of the construct from items of the new environmental paradigm scale is the starting point to measure tourist's intention reducing food waste. The next variables are feeling personal responsibility and knowledge in reducing food waste to predict tourist's intention of reducing food waste. Previous research lacks information which uses intercorrelation between those variables to measure tourist' intention reducing food waste.

Based on the aim of this study and conceptual model, six hypotheses are formulated below:

Hypothesis 1:

Environmental attitudes influence the tourist's responsibility toward reducing food waste during the holiday.

Hypothesis 2:

Environmental attitudes influence the tourist's knowledge toward reducing food waste during the holiday.
Hypothesis 3:

Environmental attitude directly influences the tourist's intention toward reducing food waste during the holiday.

Hypothesis 4:

Tourist's feeling of responsibility for reducing food waste directly influences tourist's intention toward reducing food waste during the holiday.

\section{Hypothesis 5:}

Tourist's knowledge of reducing food waste directly influence tourist's intention toward reducing food waste during the holiday

Hypothesis 6:

Tourist's knowledge of reducing food waste influences toward feeling a personal responsibility for reducing food waste during the holiday.

\section{Research Methods}

The population of this study includes local and foreign tourists who are travelling to Badung regency, Bali province. A paper-based survey method was applied to this research. The research sample is Indonesian people as domestic tourists, and also (mostly Australian and European) as a foreign visitor. The data were collected for five weeks (December 2018-January 2019). The questionnaire was distributed on the beach with the highest number tourist such as in Kuta beach and also regularly at seven cafés in Badung regency.

All the data analysed by handling IBM'S SPSS version 24 .

\section{Instrument design}

The questionnaires consisted of environmental attitude, feeling personal responsibility, knowledge and intention of reducing food waste during the holiday. The questionnaires were designed in English first and then translated into Indonesian by the author. The format to measure all items was a 5 -point Likert scale. The scale ranged from totally disagree (1) to agree (5) which was used for environmental attitude, knowledge reducing food waste, and intention reducing food waste. Whereas, for feeling personal responsibility a scale ranging from (1) strongly unfavourable to (5) strongly favourable was used. 
The environmental attitude section encompasses of 7 items of New Environmental Paradigm (NEP) Scale which depicted relation between human and environment (Dunlap \& Van Liere, 1978, Stren, Dietz and Guagnano, 1995, Dunlap and Jones, 2003). Feeling personal responsibility and knowledge in reducing food waste consisted of 10 items and five items, respectively, and seven items as well were used to establish intention in reducing food waste.

\section{Data analysis}

Firstly, 510 questionnaires were collected in Badung Regency, Bali. The second step, after collecting data, was preparing the data and making codes. Thirdly carried out frequency analysis to notice any error or missing values in the data. This procedure gave initial information about the percentage of gender, age, occupation, marital status, income and level of education. SPSS splits the information into local and foreign tourists. The next step was reliability analysis, is made to what extent items in the survey to measure latent construct internal consistency. The item has good reliability when it has $>.7$ of Cronbach alpha scored. Furthermore, to investigate which items had a good correlation with other items, and inter-item correlation of $>.4$ was found. New variables were computed to make variables with new names for variables that had a changed scored in the reliability test analysis.

The fifth step was a descriptive overview of the new variables. In this step, it divided the test into local and foreign tourists. Results of this test show mean and standard deviation for local and foreign tourists for environmental attitude, feeling personal responsibility, knowledge, and intention in reducing food waste.

This study used six hypotheses to test the correlation and regression to measure the relationship between all variables. The correlation analysis was used to see the relationship between environmental attitude to feeling personal responsibility and knowledge reducing food waste. Correlation analysis is a test which is used to measure a single relation, including the significance of that relation. It is used to see to what extent one variable interpreted for by other variables and also at a time to see what relation weak, medium or high correlation. Regression was applied to test the significance of the hypotheses. This test is similar to correlation, but the regression, analysis can test more than two independent variables of a predictor.

Besides, to see the correlation between sociodemographic relation to the variables were used, correlation, independent t-test, and one-way ANOVA tests. The correlation test was used to measure the correlation between age, education and income to variables in the conceptual model. Independent t-test was used to see differences between local and foreign tourists. Mean, $p$-value and effect size were found for environmental attitude, feeling personal responsibility, knowledge, and intention reducing food waste. To see the difference of means between two groups can be seen through t-test and it can be chosen with higher of average. The independent t-test was performed to analyse the type of tourists and gender for all variables, and finally, occupation and marital status were measured by one-way ANOVA (Ghozali, 2009).

\section{Research Findings and Discussion}

To reveal the outcome of tourist's intention reducing food waste during the holiday, needed to see the internal consistency. Table 1 shows the Cronbach's alpha of variables which is used for understanding tourist's intention reducing food waste. All the Cronbach's alpha scored above the threshold .7 (Field, 2013), except environmental attitude. It shows that environmental attitude has a lack of internal consistency rather than other variables to understanding tourist's intention reducing food waste.

Table 1. Reliability test of tourists reducing food waste

\begin{tabular}{|l|c|}
\hline \multicolumn{1}{|c|}{ Variables } & Cronbach's alpha \\
\hline Environmental attitude & .683 \\
\hline Feeling personal responsibility & .727 \\
\hline $\begin{array}{l}\text { Knowledge reducing } \\
\text { food waste }\end{array}$ & .762 \\
\hline $\begin{array}{l}\text { The intention of } \\
\text { reducing food waste }\end{array}$ & .843 \\
\hline
\end{tabular}

Furthermore, descriptive overview analysis is used to see means and standard deviation within 
all variables, both foreign and local tourist visiting Badung regency, Bali.

Table 2. Descriptive overview

\begin{tabular}{|c|c|c|c|c|}
\hline \multirow{2}{*}{ Variables } & \multicolumn{2}{|c|}{ Means } & \multicolumn{2}{c|}{$\begin{array}{c}\text { Standard } \\
\text { deviation }\end{array}$} \\
\cline { 2 - 5 } & Local & Foreign & Local & Foreign \\
\hline $\begin{array}{c}\text { Environmental } \\
\text { attitude }\end{array}$ & .43 & .29 & .76 & 1.01 \\
\hline $\begin{array}{c}\text { Feeling } \\
\text { personal } \\
\text { responsibility }\end{array}$ & 1.22 & 1.53 & .50 & .54 \\
\hline $\begin{array}{c}\text { Knowledge } \\
\text { reducing } \\
\text { food waste }\end{array}$ & 1.27 & 1.1 & .48 & .47 \\
\hline $\begin{array}{c}\text { Intention } \\
\text { reducing } \\
\text { food waste }\end{array}$ & 1.32 & 1.43 & .47 & .41 \\
\hline
\end{tabular}

Table 2 shows that the local tourists, the intention has the highest mean score compared to other concepts of reducing food waste. It means the intention of reducing food waste - followed by knowledge to reducing food waste. While in foreign tourists, feeling personal responsibility has the highest of mean scored rather than other concepts of reducing food waste. It means feeling personal responsibility is substantially important for foreign tourists to reducing food waste during the holiday - followed by the intention of reducing food waste. Both local and foreign tourists have the lowest scored of mean in the environmental attitude. Which is given from predictors to the results and in the coefficient, the table consists of Betha standardised describes which one of the independent variables the best predictor of the outcome.

\section{The relation between hypotheses of tourist's intention reducing food waste}

Hypothesis 1 had a stronger relationship to predict the relationship of tourist's feeling personal responsibility reducing food waste rather than hypothesis 6 due to the scored of hypotheses 1 closed to 1 . The $p$-value of hypothesis 1 is highly significant, but the value of hypothesis 6 is not significant, predicting tourist's feeling of personal responsibility to reduce food waste during the holiday. Furthermore, the relationship has a low to medium effect size (.27) due to the scored between .14 (low effect size) and .3 (medium effect size). The scored of Adj R2 is .07, meaning that environmental

Table 3. Correlation hypothesis 1 and 2

\begin{tabular}{|c|c|c|c|c|}
\hline Hypothesis & Relationship & $\mathrm{R}$ & $\mathrm{R} 2$ & $\mathrm{p}$-value \\
\hline $\mathrm{H} 1$ & $\begin{array}{c}\text { Environmental attitude -> feeling } \\
\text { personal responsibility }\end{array}$ & $.26^{* *}$ & .07 & .001 \\
\hline $\mathrm{H} 2$ & Environmental attitude -> knowledge & .06 & .0036 & .21 \\
\hline
\end{tabular}

Table 4. Regression analysis

\begin{tabular}{|c|c|c|c|c|c|c|}
\hline \multirow{2}{*}{ Hypothesis } & \multirow{2}{*}{ Variables } & \multicolumn{5}{|c|}{ Feeling personal responsibility } \\
\hline & & $\mathbf{R}$ & Adj R2 & Standardized & P-value & F. \\
\hline \multirow{2}{*}{ H1 H6 } & Environmental attitude & \multirow{2}{*}{.27} & \multirow{2}{*}{.07} & .25 & .0001 & \multirow{2}{*}{19.06} \\
\hline & Knowledge & & & .08 & .052 & \\
\hline & & \multicolumn{5}{|c|}{ The intention of reducing food waste } \\
\hline \multirow{3}{*}{ H3 H4 H5 } & Environmental attitude & \multirow{3}{*}{.35} & \multirow{3}{*}{.15} & -.05 & .23 & \multirow{3}{*}{22.75} \\
\hline & Feeling personal responsibility & & & .27 & .001 & \\
\hline & Knowledge & & & .20 & .001 & \\
\hline
\end{tabular}


attitude and knowledge reducing food waste. Meanwhile, knowledge has no significant relation with feeling a personal responsibility for reducing food waste. Thus, hypothesis 6 is rejected.

In hypothesis 4, the standardise had the strongest relationship to predict the relationship of tourist's intention to reducing food waste rather than hypothesis 3 and 5 due to the scored of hypotheses 4 closed to 1 . The p-value of hypothesis 4 and 5 are significant, but the value of hypothesis 3 is not significant in predicting tourist's intention of reducing food waste during the holiday. The scored of Adj R2 is .15, it means that environmental attitude, feeling personal responsibility reducing food waste and knowledge reducing food waste can explain $15 \%$ of tourist's intention reducing food waste. To conclude, there is no relation between environmental attitude and intention. Therefore it can be rejected. For hypothesis 4 and 5, the relation can be confirmed.

\section{Demographic analysis}

Based on table 5, education and income have a negative and significantly correlated with environmental attitude; besides, age has a positive relationship and significantly correlated with environmental attitude as well. Other variables such as feeling personal responsibility reducing food waste, knowledge reducing food waste to do not have a relation with age, education and income.

Type of visitor is measured through independent T-test to find out differences between local and foreign tourists. The local tourist is coded as 0 , and the foreign tourist is coded 1 when

Table 5. Correlation on demographic analysis

\begin{tabular}{|c|c|c|c|c|}
\hline \multirow{2}{*}{$\begin{array}{c}\text { Socio- } \\
\text { demographics }\end{array}$} & $\begin{array}{c}\text { Environmental } \\
\text { attitude }\end{array}$ & $\begin{array}{c}\text { Feeling personal } \\
\text { responsibility }\end{array}$ & Knowledge & Intention \\
\cline { 2 - 5 } & $.11^{* *}$ & -.02 & -.002 & .04 \\
\hline Age & $-.31 * *$ & .03 & -.02 & .08 \\
\hline Education & $-.21 *$ & .08 & -.06 & .01 \\
\hline Income & \multicolumn{2}{|c|}{} & &
\end{tabular}

Table 6. Independent t-test

\begin{tabular}{|c|c|c|c|c|}
\hline \multirow{2}{*}{} & \multicolumn{2}{|c|}{ Mean } & \multirow{2}{*}{ Difference p-value } & \multirow{2}{*}{ Effect size } \\
\cline { 2 - 4 } & Local & Foreigner & & 0.17 \\
\hline Environmental attitude & .43 & .29 & .06 & 0.62 \\
\hline Feeling personal responsibility & 1.22 & 1.53 & .001 & 0.37 \\
\hline Knowledge & 1.27 & 1.10 & .001 & 0.25 \\
\hline Intention & 1.32 & 1.43 & .001 & 0.17 \\
\hline
\end{tabular}

Table 7. One-way Anova

\begin{tabular}{|c|c|c|c|c|c|c|}
\hline & \multicolumn{3}{|c|}{ Occupation } & \multicolumn{3}{c|}{ Marital status } \\
\hline & Mean & P-value & $\eta^{2}$ & Mean & P-value & $\eta^{2}$ \\
\hline Environmental attitude & 5.41 & .001 & 0.27 & 6.17 & .001 & 0.18 \\
\hline Feeling personal responsibility & 1.58 & .001 & 0.24 & .26 & .42 & 0.06 \\
\hline Knowledge & .50 & .05 & 0.15 & .615 & .07 & 0.11 \\
\hline Intention & .25 & .26 & 0.11 & .16 & .44 & 0.06 \\
\hline
\end{tabular}


measuring independent T-test. In table 16 presents statistic group, Levene's test, T-test for equality of means and effect size. For Levene's test and T-test for equality of means are produced by independent T-test. While the effect size is calculated by dividing the difference mean between local and foreign tourist by the standard deviation of local as a control group. Furthermore, according to Cohen (1988) discloses small value to large value of effect size: $.2, .5$, and .8 respectively.

In feeling a personal responsibility to reduce food waste, it appears that foreign tourists feel more responsible for food waste reduction than local tourists. Moreover, foreign tourists have the highest intention to reduce food waste than local tourists. While, it says otherwise to the knowledge on reducing food waste, whereby local tourists appear to have more knowledge concerning food waste reduction than foreign tourists. Three variables above are significant relationship. However, on the environmental attitude, it appears to have no significant. Hence, based on table 16, it can be assumed that foreign tourists scored high than local tourists on the intention to reduce food waste during the holiday.

Feeling responsible for reducing food waste has a typical substantial relationship. Knowledge and intention reducing food waste have a minimal to typical relation. The environmental attitude has no effect size in the type of tourists.

The first analysis which is conducted to measure the effect of different occupation on four variables reducing food waste. The result of the one-way ANOVA showed statistically significant differences between environmental attitude and feeling personal responsibility reducing food waste. Both of them have typical to substantial relationship to reduce food waste due to the scored of effect size $\left(\eta^{2}\right)$ between .27 and .24. Furthermore, knowledge and intention do not have a relationship to reduce food waste.

The second analysis which was conducted to measure the effect of different marital status on four variables reducing food waste. The result of the one-way ANOVA showed statistically significant differences between environmental attitude and had a minimal to typical relation (.18). Thus, feeling personal responsibility, knowledge and intention do not have a relationship to reducing food waste.
According to the environmental psychology approach, figure 2 will present the conceptual model which influences each other concept, and figure 3 will present the differences found between local and foreign tourists in reducing food waste during the holiday.

Hypotheses 1, 4, and 5 are measured, and relationships were found. This means that, in this case, the environmental attitude influences tourists' feelings of personal responsibility; it follows that having knowledge and feeling personal responsibility are influences on tourists' intentions in the context of reducing food waste during the holiday. The following step was to check whether this also influences local and foreign tourists with regards to reducing food waste during the holiday.

Hypotheses 2, 3 and 6 were about whether the environmental attitude predicts knowledge and intention. While knowledge predicts the feeling of personal responsibility, in this research, there is not a substantial relationship found. It means that, in this research, there is no relationship found between environmental attitude (in the general context of the relationship between humans and the environment) and the psychological behaviour of tourists (knowledge and intention).

In the tourism context of the psychological behaviour of tourists, there is also no relationship between having knowledge and feeling personal responsibility and reducing food waste during the holiday. Furthermore, it is found that neither local nor foreign tourists are influenced by the environmental attitude to reduce food waste. It is concluded that the environmental attitude does not influence tourists' intention to reduce food waste during the holiday.

\section{The interesting result in this research are:}

Firstly, having a higher feeling of personal responsibility seems to mean that a tourist scores higher on connectedness to intentions and feels more responsibility for reducing the food waste; this can be seen in the tourist's intention to reduce food waste. This finding support by Kaiser (1999) that feeling personal responsibility is the huge outcome of ecological behaviours, in which people have felt more morally responsible for their environment and connecting with specific social emotions. In the other studies show that students 
Figure 2. Conceptual model of reducing food waste

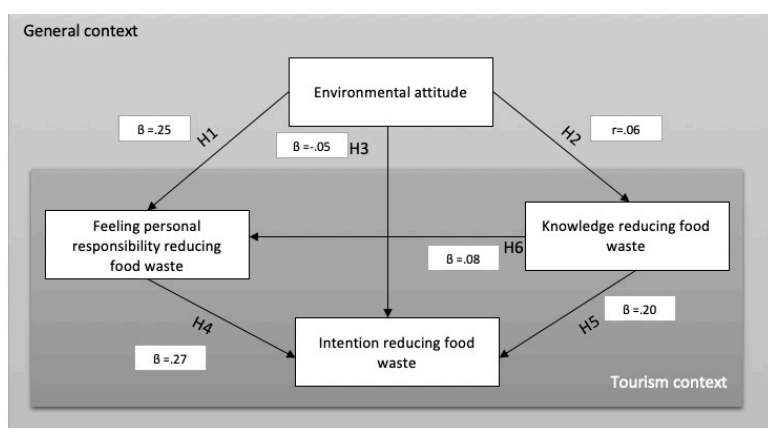

Figure 3. Scored between local and foreign tourists to reduce food waste during the holiday

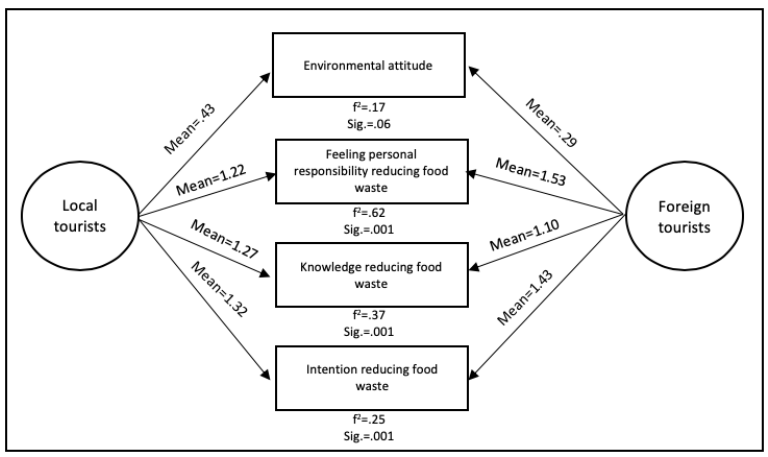

have more responsibility due to the need to protect the environment giving a positive impact on others.

Furthermore, H5 (Knowledge reducing food waste to tourist's intention reducing food waste), there is a significant relationship between knowledge and tourist's intention to reduce food waste during the holiday. That finding contrasts with Visschers et al. (2016) in which knowledge does not influence tourists' intention to reduce food waste. Visschers et al. used planned behaviour theory to be understanding tourist's intention in the household cases. Stancu et al. (2016) built a model which consists of attitudes, injunctive-norm, moral norm, and perceived behavioural control to influence people's intention not to waste food.

Attitude and injunctive-norm are significantly correlated with influencing people's intention not to waste food. On the other hand, moral norm and perceived behavioural control are not significantly correlated with influencing people's intention not to waste food in Denmark. In that study thought that student has better knowledge about an environmental problem, it can be directly understanding of their bad action giving a bad impact on the environment (Slavoljub et al., 2015).

Secondly, foreign tourists, who have the highest mean score on feeling a personal responsibility to reduce food waste. Generally, foreign tourists with higher feelings of personal responsibility know that what they are doing in respect to reduce food waste during the holiday has a positive influence as an action of proenvironmental behaviour, but their actions are less than their feelings of personal responsibility to reduce food waste during the holiday. In the other studies stated that foreign tourists had the highest appreciated towards the beauty of the scenery of the Cameron Highlands more than local tourists (Othman, 2011). It means foreign tourists did proenvironmental activities to keep the balance of nature and decrease the environmental problem.

According to Becken (2007), tourists do not agree that reducing travel is not the best way to change of tourists behavioural to be environmentalist. Lack of intention of foreign tourist in reducing food waste supported by McKercher et a. (2010) that foreign tourists had an awareness of travelling can cause adverse effects on the environment. However, foreign tourists refused to alter their behaviours.

Moreover, in local tourists, intentions are the highest score for reducing food waste. It means tourists are more prone to having the intention of reducing food waste during the holiday. Overall, local tourists with a stronger intention know that what they are doing in respect to reduce food waste during the holiday has a positive influence as an action of pro-environmental behaviour. It is similarly found from Buta et al., (2014) that local people were a part of doing conservation to preserve nature that can gain benefits for the future generation.

Thirdly, the environmental attitude does not correlate with reducing food waste and has the lowest mean score for both local and foreigner tourists for reducing food waste during the holiday. This condition is not influenced by other variables to influence tourists' intention to reduce food waste. It can be assumed that, although tourists do not have information about the general relationship between humans and the environment, they still have responsibility, knowledge, and the intention to reduce food waste during the holiday. 
There are also other studies which tried to find a relationship between the new environmental paradigm, responsibility, knowledge, and intention. In the next section of the discussion, the results of this study will be compared with the results of other studies.

\section{Findings to previous research studies}

The results confirm that $15 \%$ of model predictors explained tourists' intention to reduce food waste. This research measured a model of environmental psychology, with factors including environmental attitude, feeling personal responsibility, knowledge, and intention integrating with reducing food waste. Russell et al. (2017) tested food waste behaviours using the theory of planned behaviour variables such as attitude, subjective norm, and perceived behavioural control to predict the intention. Russell et al. (2017) explained that their model predicted $29 \%$ of the intention to reduce food waste related to emotions and habits for reducing food waste.

To predict consumer food waste behaviour, Stancu (2016) used planned behaviour theory to explain the intention and added household skills to explain food waste behaviour. This model explained that $45 \%$ of people's intention regarding not contributing to food waste, and all of the predictors explained that $43 \%$ of people's behaviour in reducing food waste. Setti et al. (2016) explained the relationship between income and food waste behaviours in households of Italian consumers. People's intention of $26 \%$ variance was explained by the TPB model, personal norms, and knowledge to reduce the amount of food waste in the households (Visschers et al., 2016).

The research found a high degree $(86 \%)$ of consumer awareness of food waste, followed by $82 \%$ awareness of the environmental impact of food waste behaviours. Kallbekken and Saelen (2013) performed research about reducing food waste in a restaurant. Their research found a $19.5 \%$ reduction of food waste in a hotel was achieved by reducing plate size, and a $20.9 \%$ reduction was achieved by giving the sign to the consumers (welcome back again and again to the restaurants).

\section{New contribution to the literature review}

The conceptual model is the first one which is used to understand tourists' intentions to reduce food waste, for which there exists no similar research. Thus, I intend to make sure that this is the first conceptual model which links value belief norm theory with the pro-environmental behaviour concerns of environmental psychology in order to understand tourists' intention to reduce food waste in tourism study.

The trend of value belief norm (VBN) theory has been used for the topic regarding the relationship between humans and the environment. Kiatkawsin and Han (2017) combined value belief norm theory and expectancy theory to describe young travellers' intentions to behave pro-environmentally. All of these factors provided a significant contribution to traveller intention to act in a pro-environmental way: $\mathrm{NEP}, \mathrm{AV}, \mathrm{BV}$, awareness of consequences, valance, the ascription of responsibility and instrumentality, but the egoistic value did not show a significant contribution.

Van Riper and Kyle (2014) also found that egoistic values had a negative influence on predicting moral norm activation in a national park. The equation model of VBN theory depicted that biospheric and altruistic values positively predict pro-environmental internal process behaviour in the national park.

Other studies used the VBN theory to explain travel mode changes in an urban population (Lind et al., 2015). This study, in particular, utilised the VBN equation, in which the components of two personal norms (biospheric and egoistic) were indirectly associated significantly the new environmental paradigm mediated that. The feeling of moral obligation and high ascription of responsibility had a strong relationship with the choice of using public transportation. Han et al. (2017) explained that VBN theory was also used to investigate customers' eco-friendly decision-making process in the cruise model. In this study, Han et al. (2017) added the emotional process as a component of the VBN theory. The results showed that the emotional process had a vital role leading to moral norms and intention.

The study from Aktas et al. (2018) explained planned behaviour theory to confirm a significant relationship between food waste and contextual factors (motive, food surplus, planning, social relationship, and others). This research told the story about food waste that came from the food 
supply chain to meet the household needs. It was an influence on food waste behaviour to minimise food waste in the household.

To conclude this section of my research, it can be determined that adding knowledge to the VBN theory was successful in understanding tourists' intentions to reduce food waste during the holiday. The conceptual model used components of VBN theory - such as the new environmental paradigm, responsibility, and components from pro-environmental concern and behaviour (knowledge) - to understand tourists' intentions to reduce food waste. However, this method was not perfect for understanding tourists' intentions to reduce food waste as opposed to using the VBN theory originally or planned behaviour theory.

\section{Demographic discussion}

The discussion of the demographics section. A variety of variables such as age, education, income, occupation and marital status has been found related to people's environmental practices (Gifford, 2014). Hence, it is potential that there are some significant relationships occur between demographics variables and tourist's intention of reducing food waste during the holiday.

In a general context, this study, age has a positive relation to environmental attitude to reducing food waste during the holiday. This means that when age increases, people feel less command intention of reducing food waste during the holiday. When age increases, it is possible if people want to think twice to decide on the intention of reducing food waste during the holiday. It was supported by Kellert (1985) said that age has a relation in people's attitude on environment and ecology.

For instance, to understand tourist's intention reducing food waste during travelling in Bali, age has a relation to environmental attitude, but there is no relation to intention reducing food waste during the holiday. Education and income have a negative relation to environmental attitude to reducing food waste during the holiday. Thus, education and income contribute to producing food waste during the holiday. Koivupuro et al. (2012) supported that education influence producing food waste in the household. Meanwhile, in income, Kolvupuro et al., (2012) said that income did not have the influence to produce waste of food in the household, because they tend to buy the cheapest products for daily needs.

In my research, there is no relation between environmental psychology approach and gender to reducing food waste during the holiday. In contrast with Kolvupuro et al. (2012) found that gender has a substantial significant relation to producing food waste in the household.

Both local and foreign tourist supported the findings of six hypotheses. This research represents that both local and foreign tourist did not influence on environmental attitude to reducing food waste during the holiday. Thus, there is no correlation between environmental attitude and nationality to reducing food waste during the holiday.

To conclude, demographic variables (age, education, income, occupation and marital status) have no significant relation on the intention of reducing the food waste during the holiday.

\section{Conclusion}

Understanding tourists' intentions to reduce food waste was divided into two contexts: general and tourism. In the general context, environmental attitude is used to predict tourists' intentions to reduce food waste. In the tourism context, feeling personal responsibility and having the knowledge to reduce food waste are used to predict tourists' intentions to reduce food waste. In the conceptual model, some hypotheses also are used to predict tourists' intentions directly from the environmental attitude in a general context. A survey was established to measure these variables which were estimated to predict tourists' intentions to reduce food waste. Data from $\mathrm{N}=510$ tourists were used, containing both local tourists $(\mathrm{N}=250)$ and foreign tourists $(\mathrm{N}=260)$. After collection, the data were analysed with correlation, regression analysis, and independent t-tests as well.

The variables were found to improve the understanding of tourists' intentions to reduce food waste. In this study, it is found that the environmental attitude has no direct relationship with tourists' intentions to reduce food waste during the holiday. On the other hand, feeling personal responsibility and having knowledge have a direct relationship with tourists' intentions to reduce food waste during the holiday. 
Regarding the second objective, it is found overall that neither local nor foreign tourists are influenced by environmental attitude (in the general context). However, variables such as the feeling of personal responsibility, knowledge, and the intention to reduce food waste influence whether tourists reduce food waste during the holiday. In particular, feeling personal responsibility has a substantial influence on both local and foreign tourists to reduce food waste during the holiday. It is found that foreign tourists have greater intention to reduce food waste than local tourists during the holiday. To summarise this research, the environmental attitude does not influence tourists' intention to reduce food waste during the holiday. Tourists may still be aware of the environmental impact of reducing food waste during the holiday, although they do not take into account their environmental attitude.

\section{References}

Ajzen, I. (1985). From intentions to actions: A theory of planned behavior. In Action control (pp. 11-39). Berlin: Springer.

Ajzen, I. (2005). Attitudes, personality, and behavior. United Kingdom: McGraw-Hill Education.

Aktas, E., Sahin, H., Topaloglu, Z., Oledinma, A., Huda, A. K. S., Irani, Z., ... \& Kamrava, M. (2018). A consumer behavioural approach to food waste. Journal of Enterprise Information Management, 31(5), 658-673.

Arbuthnot, J.(1977). The roles of attitudinal and personality variables in the prediction of environmental behavior and knowledge. Environment and behavior, 9(2), 217-232.

Badung Produksi 286 Ton Sampah Per Hari, 40\% dari Sektor Pariwisata | Beritabali.com. (2018). Retrieved from https://www.beritabali.com/ read/2018/11/23/201811230007/BadungProduksi-286-Ton-Sampah-Per-Hari-40-dariSektor-Pariwisata.html

Becken, S. (2007). Tourists' perception of international air travel's impact on the global climate and potential climate change policies. Journal of sustainable tourism, 15(4), 351-368.

Barr, S. (2003). Strategies for sustainability: citizens and responsible environmental behaviour. Area, 35(3), 227-240.

Bonnes, M. (2017). Psychological theories for environmental issues. Routledge.

Buta, N., Holland, S. M., \& Kaplanidou, K. (2014). Local communities and protected areas: The mediating role of place attachment for pro-environmental civic engagement. Journal of Outdoor Recreation and Tourism, 5, 1-10.

Central Bureau of Statistics of Badung Regency (2010). Badung in figure 2010. Retrieved from http://datin.menlh.go.id/assets/berkas/DDAKabupaten kota/Kab-Badung-2010.pdf

Central Bureau of Badung Regency (2019). Kunjungan Wisatawan di Bali pada 2015 sampai 2017.

Central Bureau of Statistics of Badung Regency (2019). Perkembangan Pariwisata Provinsi Bali April 2019.

Chawla, L. (1999). Life paths into effective environmental action. The Journal of Environmental Education, 31(1), 15-26.

Cohen, J. (1988). Statistical power analysis for the behaviors science (2nd). New Jersey: Laurence Erlbaum Associates, Publishers, Hillsdale.

Cottrell, S. P. (2003). Influence of sociodemographic and environmental attitudes on general responsible environmental behavior among recreational boaters. Environment and behavior, 35(3), 347375.

Erkmen, E., \& Hancer, M. (2018). Creating value for restaurant customer: The role of other customers in dining experience. In Tourist Behavior (pp. 157-171). Springer, Cham.

De Groot, J. I., \& Steg, L. (2009). Morality and prosocial behavior: The role of awareness, responsibility, and norms in the norm activation model. The Journal of social psychology, 149(4), 425-449.

Dunlap, R. E., \& Van Liere, K. D. (1978). The "new environmental paradigm". The journal of environmental education, 9(4), 10-19.

Dunlap, R. E., Van Liere, K. D., Mertig, A. G., \& Jones, R. E. (2000). New trends in measuring environmental attitudes: measuring endorsement of the new ecological paradigm: a revised NEP scale. Journal of social issues, 56(3), 425-442

Dunlap, R. E., \& Jones, R. E. (2003). Environmental attitudes and values. Encyclopaedia of psychological assessment, 1, 364-369.

Field, A. (2013). Discovering statistics using IBM SPSS statistics. United Kingdom: SAGE Publications.

Fishbein, M., Jaccard, J., Davidson, A. R., Ajzen, I., \& Loken, B. (1980). Predicting and understanding family planning behaviors. In Understanding attitudes and predicting social behavior. Prentice Hall.

Ficko, A., \& Bončina, A. (2019). Public attitudes toward environmental protection in the most developed countries: The Environmental Concern Kuznets Curve theory. Journal of environmental 
management, 231, 968-981.

Fixing food: towards a more sustainable food system. (2016). Retrieved from http://foodsustainability. eiu.com/wp-content/uploads/sites/34/2016/11/ Barilla-Fixing-Food.pdf

Ghozali, I. (2009). Ekonometrika Teori, Konsep dan Aplikasi dengan SPSS 17. Semarang: Badan Penerbit Universitas Diponegoro.

Graham-Rowe, E., Jessop, D. C., \& Sparks, P. (2014). Identifying motivations and barriers to minimising household food waste. Resources, conservation and recycling, 84, 15-23.

Gifford, R., \& Sussman, R. (2012). Environmental attitudes. The Oxford handbook of environmental and conservation psychology, 65-80.

Gifford, R., \& Nilsson, A. (2014). Personal and social factors that influence pro $\square$ environmental concern and behaviour: A review. International Journal of Psychology, 49(3), 141-157.

Go for Zero Food Waste Lifestyle | ecoBali Recycling. (2018). Retrieved from http://eco-bali.com/gozero-food-waste-lifestyle/

Granzin, K. L., \& Olsen, J. E. (1991). Characterizing participants in activities protecting the environment: A focus on donating, recycling, and conservation behaviors. Journal of Public Policy \& Marketing, 10(2), 1-27.

Ha, J., \& Jang, S. S. (2010). Perceived values, satisfaction, and behavioral intentions: The role of familiarity in Korean restaurants. International Journal of Hospitality Management, 29(1), 2-13.

Han, H., Hsu, L. T. J., \& Sheu, C. (2010). Application of the theory of planned behavior to green hotel choice: Testing the effect of environmentally friendly activities. Tourism management, 31(3), 325-334.

Han, Heesup, Jinsoo Hwang, and Myong Jae Lee. "The value-belief-emotion-norm model: Investigating customers' eco-friendly behavior." Journal of Travel \& Tourism Marketing34.5 (2017): 590607.

Harland, P., Staats, H., \& Wilke, H. A. (2007). Situational and personality factors as direct or personal norm mediated predictors of proenvironmental behavior: Questions derived from norm-activation theory. Basic and applied social psychology, 29(4), 323-334.

Heberlein, T. A., \& Black, J. S. (1976). Attitudinal specificity and the prediction of behavior in a field setting. Journal of Personality and Social Psychology, 33(4), 474.

Hines, J. M. (1984). Analysis and synthesis of research on responsible environmental behavior. USA: Southern Illinois Univ.
Juvan, E., \& Dolnicar, S. (2017). Drivers of proenvironmental tourist behaviours are not universal. Journal of Cleaner Production, 166, 879-890.

Kaiser, F. G., Wölfing, S., \& Fuhrer, U. (1999). Environmental attitude and ecological behaviour. Journal of environmental psychology, 19(1), 1-19.

Kellert, S. R. (1985). Attitudes toward animals: Agerelated development among children. In Advances in Animal Welfare Science 1984 (pp. 43-60). Springer, Dordrecht.

Keisha (2019). Bali Buda, zero waste: Interview

Kiatkawsin, K., \& Han, H. (2017). Young travelers' intention to behave pro-environmentally: Merging the value-belief-norm theory and the expectancy theory. Tourism Management, 59, 76-88.

Kivela, J., Inbakaran, R., \& Reece, J. (2000). Consumer research in the restaurant environment. Part 3: analysis, findings and conclusions. International Journal of Contemporary Hospitality Management, 12(1), 13-30.

Kollmuss, A., \& Agyeman, J. (2002). Mind the gap: why do people act environmentally and what are the barriers to pro-environmental behavior? Environmental education research, 8(3), 239-260.

Koivupuro, H. K., Hartikainen, H., Silvennoinen, K., Katajajuuri, J. M., Heikintalo, N., Reinikainen, A., \& Jalkanen, L. (2012). Influence of socio $\square$ demographical, behavioural and attitudinal factors on the amount of avoidable food waste generated in Finnish households. International journal of consumer studies, 36(2), 183-191.

Lee, J. S. H., \& Oh, C. O. (2018). The Causal Effects of Place Attachment and Tourism Development on Coastal Residents' Environmentally Responsible Behavior. Coastal management, 46(3), 176-190.

Lee, T. H. (2013). Environmentally responsible behavior of nature-based tourists: related concepts, measurement, and research. Journal of Tourism\&Hospitality, 2(2), 1-2.

Lind, H. B., Nordfjærn, T., Jørgensen, S. H., \& Rundmo, T. (2015). The value-belief-norm theory, personal norms and sustainable travel mode choice in urban areas. Journal of Environmental Psychology, 44, 119-125.

Lindenberg, S., \& Steg, L. (2007). Normative, gain and hedonic goal frames guiding environmental behavior. Journal of Social issues, 63(1), 117137.

Maloney, M. P., Ward, M. P., \& Braucht, G. N. (1975). A revised scale for the measurement of ecological attitudes and knowledge. American 
psychologist, 30(7), 787.

McKercher, B., Prideaux, B., Cheung, C., \& Law, R. (2010). Achieving voluntary reductions in the carbon footprint of tourism and climate change. Journal of sustainable tourism, 18(3), 297-317.

Miller, D., Merrilees, B., \& Coghlan,A. (2015). Sustainable urban tourism: understanding and developing visitor pro-environmental behaviours. Journal of Sustainable Tourism, 23(1), 26-46.

Namkung, Y., \& Jang, S. (2007). Does food quality really matter in restaurants? Its impact on customer satisfaction and behavioral intentions. Journal of Hospitality \& Tourism Research, 31(3), 387-409.

Othman, J. (2011). Scenic beauty preferences of Cameron Highlands Malaysia: Local versus foreign tourists. International Journal of Business and Social Science, 2(6), 248-253.

Pienaar, E. F., Lew, D. K., \& Wallmo, K. (2013). Are environmental attitudes influenced by survey context? An investigation of the context dependency of the New Ecological Paradigm (NEP) Scale. Social science research, 42(6), 1542-1554.

Polonsky, M. J., Vocino, A., Grau, S. L., Garma, R., \& Ferdous, A. S. (2012). The impact of general and carbon-related environmental knowledge on attitudes and behaviour of US consumers. Journal of Marketing Management, 28(3-4), 238-263.

Raajpoot, N. A. (2002). TANGSERV: A multiple item scale for measuring tangible quality in foodservice industry. Journal of Foodservice Business Research, 5(2), 109-127.

Russell, S. V., Young, C. W., Unsworth, K. L., \& Robinson, C. (2017). Bringing habits and emotions into food waste behaviour. Resources, Conservation and Recycling, 125, 107-114.

Slavoljub, J., Zivkovic, L., Sladjana, A., Dragica, G., \& Zorica, P. S. (2015). To the environmental responsibility among students through developing their environmental values. Procedia-Social and Behavioral Sciences, 171, 317-322.

Sulek, J. M., \& Hensley, R. L. (2004). The relative importance of food, atmosphere, and fairness of wait: The case of a full-service restaurant. Cornell Hotel and Restaurant Administration Quarterly, 45(3), 235-247.

Susskind, A. M., \& Chan, E. K. (2000). How Restaurant Features Affect Check Aberages: A Study of the Toronto Retaurant Market. Cornell Hotel and Restaurant Administration Quarterly, 41(6), 56-63.

Stancu, V., Haugaard, P., \& Lähteenmäki, L. (2016). Determinants of consumer food waste behaviour: Two routes to food waste. Appetite, 96, 7-17.

Stern, P. C., Dietz, T., \& Guagnano, G. A. (1995). The new ecological paradigm in social-psychological context. Environment and behavior, 27(6), 723743

Stern, P. C. (2000). New environmental theories: toward a coherent theory of environmentally significant behavior. Journal of social issues, 56(3), 407424.

Taufique, K.R., Siwar, C., Chamhuri, N., Sarah, F.A. (2016). Integrating General Environmental Knowledge and Eco-Label Knowledge in Understanding Ecologically 66 Conscious Consumer Behavior. Procedia Economics and Finance 37, 2016: 39 - 45.

Van Liere, K. D., \& Dunlap, R. E. (1977). Moral Norms and Environmental Behavior: An Application of Schwartz's Norm $\square$ Activation Model to Yard Burning 1. Journal of Applied Social Psychology, 8(2), 174-188.

Van Riper, C. J., \& Kyle, G. T. (2014). Understanding the internal processes of behavioral engagement in a national park: A latent variable path analysis of the value-belief-norm theory. Journal of Environmental Psychology, 38, 288-297.

Visschers, V. H., Wickli, N., \& Siegrist, M. (2016). Sorting out food waste behaviour: A survey on the motivators and barriers of self-reported amounts of food waste in households. Journal of Environmental Psychology, 45, 66-78.

Wang, P., Liu, Q., \& Qi, Y. (2014). Factors influencing sustainable consumption behaviors: a survey of the rural residents in China. Journal of Cleaner Production, 63, 152-165. 